\title{
Strategic Factors Influencing the Destination Choice for Domestic Tourists in Kenya
}

\author{
Mwanthi John Mawioo ${ }^{1}$, Dr. Assumptah W. Kagiri ${ }^{2}$ \\ MBA - Jomo Kenyatta University of Agriculture and Technology \\ Lecturer - Jomo Kenyatta University of Agriculture and Technology
}

\begin{abstract}
The purpose of this study was to find out the strategic factors that influence the destination choice for domestic tourists in Kenya. The study objectives included; assessing the effect of community based tourism on domestic tourists' decision to travel within Kenya, determining the effect of infrastructure development on domestic tourists' decision to travel within Kenya, evaluating the effect of safety and security on domestic tourists' decision to travel within Kenya and finally determining how the price of a tour package affects the domestic tourists' decision to travel within Kenya. The importance of tourism to the Kenyan economy cannot be over emphasized, it being one of the country's biggest foreign exchange earners and providing thousands of both direct and indirect employment. It is also through tourism that the country embarks on its efforts at protecting one of its major sources of pride - Wildlife. The population of interest in this study was Kenyan holiday goers within Nairobi's CBD. The study used primary data collected using a structured questionnaire. Data obtained from the research was coded and keyed into the Statistical Package for Social Science (SPSS) analysis software using multiple linear regressions. Results showed that $73.7 \%$ of domestic tourists visit areas because of the local communities and their way of life, $54.9 \%$ of domestic tourists will choose a destination if it has well developed infrastructure, $59.2 \%$ of domestic tourists will choose a destination if it is safe and secure and that $68.4 \%$ domestic tourists will choose a destination because of the pricing. The study recommends that the government should increase security in the tourist attraction areas so that the tourism sector can be revived by attracting domestic as well international tourists and that players in the tourism industry including hotels and national parks should price their services reasonably in order to attract large number of domestic tourists to increase revenues now the international ones have been scared away by terrorism and insecurity. The study also recommends that communities should exploit their culture and tradition to attract domestic tourists.
\end{abstract}

Keywords: Factors, Destination Choice, Domestic Tourists

\section{Introduction}

Tourism is recognized as one of the key sectors of development in all countries and a major source of income, jobs and wealth creation (Dupeyras and MacCallum, 2013). According to WTO (2012), tourism includes activities where people travel to and stay in locations outside their usual surrounding for a period of not more than one consecutive year of leisure business or other purposes. It forms one component of the activities undertaken during a period of leisure (Holloway, Humphreys and Davidson, 2009). Initially, tourism was perceived to only include leisure but with passage of time, tourism scope has expanded to include such disciplines as wellness, education, conferences, sports, seminars and religion (Konu and Laukkanen, 2009). Swarbrooke and Horner (2007) and Ryan (1997) argue that the attractiveness of a tourist destination varies from one individual to another depending on the circumstances in which they make the decision. The decision by an individual to tour a given site is influenced by both destination features which make up the destination attractiveness and the individuals knowledge on such a destination.

Many African countries are blessed with numerous tourist resorts and attractions. Despite this fact, the foregoing benefits have not helped the people of this continent due to the poor state of the industry and ensuing low patronage, and inadequate government attention (Olorunfemi and Raheem, 2008). Quite recently, governments of developing countries began to commit huge financial resources to the sector; particularly the hospitality and nature reserve (parks) sectors, because of the realization that the industry is a veritable tool for poverty alleviation, attainment of the millennium goals (MDGs), and sustainable development. A negative factor related to tourism in many African countries is the perception people have of safety and security issues (Dieke, 2000).

The tourism and hospitality industry is among the fastest growing in the world. The industry contributes significantly in poverty reduction and hence the achievement of the UN millennium development goals (UNMDGs) 1, 3, 7 and 8 . Tourism is an industry that can thrive in poverty stricken areas and hence raise the living standards of the people because it doesn't need high skills.

Despite the fact that the tourism and hospitality sector is significantly growing in Africa where poverty incidences are rampant, such growth doesn it seem to translate one for one into poverty reduction. A majority of governments in Africa are unable to capture much of the income generated from tourism. With only few years left until the target date for UNMDGs, there is a need for accelerated progress to foster the tourism and hospitality sectores contribution to development (AJTH, 2015). Measures must be taken to address the myriad problems bedeviling the tourism industry in order to realize the UNMDGs and turn the African economy into a middle income economy (AJTH, 2015).

\subsection{Tourism in Kenya}

According to Ondicho (2000), tourism in Kenya was instituted during the colonial period as a leisure-oriented activity for which only Europeans were equipped culturally, 


\section{International Journal of Science and Research (IJSR) \\ ISSN (Online): 2319-7064 \\ Index Copernicus Value (2013): 6.14 | Impact Factor (2014): 5.611}

economically and socially to take part in, and around which they reserved for themselves the right to undertake entrepreneurial activity. The clientele comprised mainly of settler holiday makers from the other parts of East Africa, Rhodesia (Zimbabwe), prospective settlers from Southern Africa and, the United Kingdom. Policies were eventually enacted that greatly increased the country"s involvement in tourism. Among other policies, the National Parks Ordinance was instituted in 1945 "to provide for the establishment of national parks and for preservation of wildlife; wild vegetation and objects of aesthetic, geological, prehistoric, archaeological, and historical or other scientific interest therein and for incidental matters relating thereto.

Today, Kenya's tourism market is diverse, with natural attractions and an attractive coastline with relatively well developed resorts. With the government also actively supporting the tourism industry, it has the potential to attract a large number of inbound arrivals. Unfortunately, the security situation in the country and the perceived threat of Ebola have contributed to a disappointing forecast over the next few years, with the value of the hotel and restaurant industry expected to fall by $10 \%$ between 2015 and 2019 . As a result, the country is a higher risk proposition for tourism investment than a number of other countries in the region (WTTC, 2014).

According to the World Travel and Tourism Council report of 2014, the direct contribution of Travel and Tourism to Kenya's GDP in 2013 was KES183.4bn (4.8\% of GDP). This primarily reflects the economic activity generated by industries such as hotels, travel agents, airlines and other passenger transportation services (excluding commuter services). But it also includes, for example, the activities of the restaurant and leisure industries directly supported by tourists (WTTC, 2014).

The tourism sector in the country created 226,500 jobs directly in 2013 (4.1\% of total employment). This includes employment by hotels, travel agents, airlines and other passenger transportation services (excluding commuter services). It also includes the activities of the restaurant and leisure industries directly supported by tourists. By 2024, it is forecasted that Travel and Tourism will account for 284,000 jobs directly, an increase of $2.3 \%$ pa over the next ten years (WTTC, 2014).

Tourism in Kenya faces numerous challenges such as unsystematic tourism planning, lack of tourism awareness, insecurity, and bad publicity, stiff competition from other countries, poor road infrastructure and narrow range of tourism products (Manyara and Jones 2007). The Kenyan government faces a difficult task to convince tourists to visit in such uncertain times. Undoubtedly it has to tackle the security situation in the country, as remaining on the travel advisory lists of many western governments has a negative effect, which is accentuated by high profile terrorist incidents, such as the September 2013 attack in the Westgate Shopping Centre in Nairobi.

Not many Kenyans travel for holiday purposes or consume traditional tourism products and services such as paid for accommodation, tour busses and rental cars, or visit tourist attractions. A similar scenario was found in South Africa when holiday-taking was not universal among the adult population (Bresler, 2011). This is unlike in Australia where domestic tourism dominates most of the tourism business. For the year ended 30th June 2007, there were 74 million domestic visitors in Australia, whereas the number of international tourist arrivals was only five million (Travel by Australians: June 2007). Furthermore, domestic visitors spent 288 million nights in Australia, while international visitors only spent 160 million nights. In terms of generating tourism revenue, the total spending by domestic visitors in 2007 was AUD 43 billion, which was 1.5 times higher than the aggregate expenditure by international tourist arrivals.

Large scale domestic tourism was promoted in these societies for leisure and recreation purposes. Domestic tourism leads to an overall development of personality, which in turn helps the economy and finally improves the standard of living (Kreck, 2010). Tourism development normally follows an industrialization and urbanization process which brings about economic and social changes, and affords people more leisure time and disposable income (Urry, 2002).

The main objective of this study was to determine the strategic factors influencing the destination choice for domestic tourists in Kenya.

\section{Specific Objectives}

1) To assess the effect of community based tourism on destination choice for domestic tourists in Kenya.

2) To determine the effect of infrastructure development on destination choice for domestic tourists in Kenya.

3) To assess the effect of safety and security on destination choice for domestic tourists in Kenya.

4) To determine how the price of a tour package affects the destination choice for domestic tourists in Kenya.

\section{Literature Review}

\subsection{Theoretical Framework}

This section presents the theoretical anchorage of the study. It specifically discusses three theories that guide this study: rational choice theory, Porter's Theory of Competitive Advantage and the Theory of Planned Behavior. These theories are discussed in details below.

\subsubsection{Rational Choice Theory}

Rational Choice Theory (RCT), which is also called Rational Actor Theory, has its origins in microeconomics but has been used in a variety of academic fields (Lindauer, 2009). In rational choice theories, individuals are seen as motivated by the wants or goals that express their 'preferences'. They act within specific, given constraints and on the basis of the information that they have about the conditions under which they are acting. At its simplest, the relationship between preferences and constraints can be seen in the purely technical terms of the relationship of a means to an end.

As it is not possible for individuals to achieve all of the various things that they want, they must also make choices

\section{Volume 4 Issue 11, November 2015}




\section{International Journal of Science and Research (IJSR) \\ ISSN (Online): 2319-7064 \\ Index Copernicus Value (2013): 6.14 | Impact Factor (2014): 5.611}

in relation to both their goals and the means for attaining these goals. Rational choice theories hold that individuals must anticipate the outcomes of alternative courses of action and calculate that which will be best for them. Rational individuals choose the alternative that is likely to give them the greatest satisfaction (Schram and Caterino, 2006).

\subsubsection{Porter's Theory of Competitive Advantage}

"Sustainable competitive advantage" is a term used by Porter (2008) when he discusses the basic types of competitive strategies that a firm can possess (low cost or differentiation) in order to achieve a long run sustainable competitive advantage. In his book Competitive Advantage: Creating and sustaining superior performance, Porter explains the requisite approach to business success. Sustainable competitive advantage means sustainable superior performance. He goes ahead to state that structural conditions of an industry as proposed in his 5 Forces model determine average industry performance. Relatively strong competitive position and performance of a particular firm in an industry derives from two types of competitive advantage i.e. low costs and differentiation (Porter, 2008). The two approaches are not however alternatives because even when competition is based on differentiation, costs still do matter.

Porter's approach suggests that differentiation and cost leadership seek competitive advantage in a broad range of market or industry. By contrast differentiation focus and cost focus strategies are adopted in a narrow market industry. Differentiation involves selecting one or more criteria used by buyers in a market and then positioning the business uniquely to meet those criteria (Porter and Kramer, 2006). The strategy involves charging a premium for the product often to reflect higher production cost and extra value added features provided for the consumer, e.g. Priority Banking at Standard Chartered Bank (K) Limited and Premiere Banking at Barclays Bank of Kenya Limited.

For cost leadership strategy, the objective of the firm is to become the lowest cost producer in the industry. If achieved the selling price can at least equal (or nearly) the average for the market then the lowest cost producer will enjoy the best profits. A strategy usually associated with large scale business offering standard products. Cost focus strategy is for businesses that seeks a lower cost advantage in just one or a smaller number of market segments. The product will be basic-perhaps a similar product to the high priced and featured market leader - but acceptable to sufficient customers. Porter's approach however raises fundamental questions; why does the successful firm not buy the unsuccessful firm and teach it how to minimize costs? Why does the successful firm not sell its expertise in cost reducing to less successful firms? Why does the successful firm not cut its prices and drive its competitors out of business? Why does the unsuccessful firm not hire the executive in charge of cost drivers from the successful firm? (Porter and Kramer, 2006)

A business aiming to differentiate within just one or small number of target markets segments is viewed as applying the differentiation focus strategy. The special customer needs means that there are opportunities to provide products that are clearly different from competitors who may be targeting a broader group of customers (Porter, and Kramer, 2006). Important issue being that the business ensures that customers really do have different needs and wants i.e. there is a valid basis for differentiation and that existing competitors are not meeting those needs and wants. This strategy is common amongst niche retailers

\subsubsection{Theory of Planned Behaviour}

In psychology, the theory of planned behavior (abbreviated TPB) is a theory which links beliefs and behavior. The concept was proposed by Icek Ajzen to improve on the predictive power of the theory of reasoned action by including perceived behavioural control (Ajzen, 2002). Behaviour is said to be approximately equal to behavioural intention, which can be derived from a combination of the consumer's attitude toward purchasing the product and the subjective norms about the behaviour. Through the concept of ,subjective norm ${ }^{\text {ee }}$ the theory acknowledges the power of other people in influencing behaviour (Solomon, RussellBennett and Previte, 2012).

The theory accounts for the thoughts of others toward the certain behaviour, and is moderated by the extent to which the consumer is motivated to comply to these views. The relative contributions of attitudes and subjective norms will not necessarily be equal in predicting behaviour (Miller, 2005), depending on the individual consumer's propensity to care about otheres views, the consumption situation, or the product type under consideration, with conspicuously consumed products tending to be influenced to a greater degree by the subjective norm variable than less conspicuous products would be (Schultz, 2006).

Another notable change in approach seen in TRA is that attitude toward the behaviour (the act of buying) is measured rather than simply the attitude toward the object. This was a necessary amendment once behaviour was being measured, as a consumer may have a very favourable attitude toward a product, but not toward the act of purchasing it (Solomon, Russell-Bennett and Previte, 2012).

\subsection{Conceptual Framework}

Kothari (2004) defines conceptual framework as a structure that defines the interrelationship between variables deemed important in a study. He further explains that it expresses the researcheres views about the constructs deemed important in a study. In this study the researcher views domestic tourists ${ }^{\text {ee }}$ decision to travel to a destination of choice in Kenya to be influenced by infrastructure development, safety and security, community based tourism and finally price of tour packages. This is represented below.

\subsection{Research Gap}

There is no research found on decision criteria for the selection of Kenyan domestic tours for an untapped market. There is a research gap in domestic tourism, especially from a consumer perspective in situation-specific contexts According to Hudson and Ritchie (2002), domestic tourism is of the most neglected and under-researched categories in tourism analysis.

\section{Volume 4 Issue 11, November 2015}




\section{Research Methodology}

\subsection{Introduction}

The chapter described the proposed research method. This includes the research design, target population, sample design, data collection and techniques for data analysis.

\subsection{Research Design}

In this research, a cross sectional survey approach was adopted since the study investigated the influence of destination attractiveness strategies on domestic touristse decision to travel to a destination of choice in Kenya. The research took a survey design. Survey is a measurement process used to collect information during a highly structured interview.

\subsection{Target Population}

The population of interest in this study was Kenyan holiday goers within Nairobies CBD. According to the Kenya Association of Tour Operator's (KATO Travel Agents Magazine 2015), there are 357 members. The study focused on the tour operators based in city CBD to get to their customers. The target population therefore comprised of clients of the 35 CBD KATO members.

\subsection{Sample Size and Sampling Technique}

The sample size was 105 clients chosen through simple random sampling from the 35 KATO members found in Nairobi CBD, 3 clients from each company. The study adopted convenient sampling by sampling domestic customers of the KATO members found within Nairobi CBD. Simple random sampling refers to a sampling method that has the following properties.

- The population consists of $N$ objects.

- The sample consists of $n$ objects.

- All possible samples of $n$ objects are equally likely to occur.

An important benefit of simple random sampling is that it allows researchers to use statistical methods to analyze sample results. Sample size formula for simple random sampling (SRS) with the finite population correction factor (fpc)

$$
n_{s r s}=\frac{N \hat{p}_{s r s} \hat{q}_{s r s}}{\frac{d^{2}}{1.96^{2}}(N-1)+\hat{p}_{s r s} \hat{q}_{s r s}}
$$

where

$n_{s r s}=$ samplesize

$N=$ populationsize

$\hat{p}_{s r s}=$ the estimated proportion

$\hat{q}_{s r s}=1-\hat{p}_{s r s}$

$d=$ desired absolute precision

\subsection{Data Analysis}

Data analysis involves assigning meaning to the data collected (Gliner and Morgan, 2000). It involves working with data, organizing it, breaking it into manageable units, synthesizing it, searching for patterns, discovering what is important and what is to be learned and, deciding what will be reported (Connaway and Powell, 2010). Data obtained from the research was coded and keyed into the Statistical Package for Social Science (SPSS) analysis software using multiple linear regressions.

Suppose $Y$ is a dependent variable, and $X$ is an independent variable. The population regression line is:

$$
\mathrm{Y}_{\mathrm{i}}=\mathrm{B}_{0}+\mathrm{B}_{1} \mathrm{X}_{1}+\mathrm{B}_{2} \mathrm{X}_{2}+\mathrm{B}_{3} \mathrm{X}_{3}+\mathrm{B}_{4} \mathrm{X}_{4}+\mathrm{e}_{\mathrm{o}}
$$

Where $\mathrm{B}_{0}$ is a constant, $\mathrm{B}_{1}$ is the regression coefficient, $\mathrm{X}$ is the value of the independent variable, and $Y$ is the value of the dependent variable.

According to Gliner and Morgan (2000), quantitative data analysis may involve using descriptive statistics to obtain an understanding of the data. For the open ended questions, the study will use content analysis.

\subsection{Presentation of Findings}

After analysis, the analyzed information was presented in the form of tables, charts and graphs. Frequency distribution tables were used together with percentages for general information questions while descriptive statistics including mean and standard deviation will be used for Likert scale questions.

\section{Summary of the Findings}

This section presents a summary of findings according to the objectives of the study. It starts with findings on the influence of community based tourism on the choice of destination; influence of infrastructure development on the choice of destination; influence of safety and security on the choice of destination; and the influence of price on the choice of destination.

\section{Influence of Community Based Tourism on the Choice of Destination}

On whether community based tourism was the reason as to why respondents visited the particular destination, the majority, $73.7 \%$ said they visited because of the local community as compared to $26.3 \%$ who said that the reason they visited the area was not because of the local community. On whether the respondents liked the peoplees traditional food and drinks had the highest mean of 4.125 followed by that the local community is the reason respondents travelled to the destination with a mean of 4.123 , the community there is hospitable had a mean of 4.023I while the respondents felt local community benefits from the tourists had a mean of 2.632 . 


\section{Influence of Infrastructure Development on the Choice of Destination}

On whether well developed infrastructure was the reason as to why respondents visited the particular destination, a majority of $54.9 \%$ said that they traveled to the destination because of the well developed infrastructure as compared to $46.1 \%$ who said that well developed infrastructure was not the reason as to why they traveled to the destination while the majority.

On whether the respondents chose a destination based on the reliability of transport services had the highest a mean of 4.875 followed by the respondents chose a destination based on the condition of roads with a mean of 4.452, the respondents chose the destination as a result of its accessibility with a mean of 4.321 , respondents chose a destination based on adequate hotels and restaurants with a mean of 3.987 , respondents chose the destination as it has less human habitation and infrastructure had a mean of 3.985, respondents chose the destination because of its scenery a mean of 3.875 , respondents chose a destination based on the ambience of the hotels 3.762, respondents chose a destination based on the availability of communication services had a mean of 3.492 and whether respondents chose a destination based on good drainage system had a mean of 2.956 .

\section{Influence of Safety and Security on the Choice of Destination}

On whether well safety and security was the reason as to why respondents visited the particular destination, the majority of $59.2 \%$ said that they chose to visit the particular destination because it was safe and secure as compared to $40.8 \%$ who said they did not choose to visit the particular destination because it was safe and secure. On whether safety and security has to be enhanced had the highest mean of 4.897 followed by whether respondents felt safe at the destination with a mean of 3.323 , health and safety measures at the destination was assured had a mean of 3.245 , there is good community relationship/co-existence in the area had a mean of 3.145 and on whether safety and security was the main determinant in choice of destination had a mean of 3.045 .

\section{Influence of Price on the Choice of Destination}

On whether well price of tour package was the reason as to why respondents visited the particular destination a majority of $68.4 \%$ said that they chose to visit the particular destination because of the pricing of the tour package as compared to $31.6 \%$ that said they did not choose to visit the particular destination because of the pricing. Whether price was the main determinant in choice of destination had the highest mean of 4.321 followed by that the destination does not give value for money with a mean of 3.985, whether there is a price difference for domestic and international tourists had a mean of 3.875 , whether the price of the destination is overrated a mean of 3.762, whether the food is reasonably priced 3.052 , whether recreational activities are reasonably priced had a mean of 2.975 and whether entry charges are reasonable had a mean of 2.967 .

\section{Conclusions}

On influence of community based tourism on the choice of destination, it was concluded that most domestic tourists visit community based tourist areas because they like the local communities and their way of life and that of all the things in the local community they like the peoplees traditional food and drinks most.

On influence of infrastructure development on the choice of destination, the study concludes that most domestic tourists will choose a destination if it has well developed infrastructure. The study also concludes that reliability of transport services has the biggest influence on domestic tourists ${ }^{\text {ee }}$ choice of destination of all infrastructure attributes followed as well as the condition of roads and adequacy of hotels.

On influence of safety and security on the choice of destination, the study concludes that most domestic tourists will choose a destination if it is safe and secure. The study also concludes that most domestic tourists believe that safety and security has to be enhanced even though the health and safety measures at the destination they had visited.

On influence of price of tour package on the choice of destination, the study concludes that most domestic tourists will choose a destination because of the pricing. The study also concludes that price is the main determinant in choice of destination for local tourist, most of them also feeling that they do not get the value for their money.

\section{Recommendations}

It was reccomended that the government should increase security in the tourist attraction areas so that the tourism sector can be revived by attracting domestic as well international tourists. The government should also ensure that these areas are accessible and have communication services. This can be achieved by partnering with the private sector.

Because many of the domestic tourists visit community based tourism areas, the study recommends that local communities should exploit their culture and tradition to attract domestic tourists.

Finally, the study recommends that players in the tourism industry including hotels and national parks should price their services reasonably in order to attract large number of domestic tourists to increase revenues now the international ones have been scared away by terrorism and insecurity.

\section{Recommendations for Further Studies}

This study sought to investigate the strategic factors influencing the destination choice for domestic tourists in Kenya. This study therefore recommends that in the future a similar study be conducted the strategic factors influencing 


\section{International Journal of Science and Research (IJSR) \\ ISSN (Online): 2319-7064 \\ Index Copernicus Value (2013): 6.14 | Impact Factor (2014): 5.611}

the destination choice for international tourists in Kenya so that a generalization can be done on the strategic factors influencing the destination choice for tourists in Kenya.

The study also recommends that in the future a study be conducted on the strategies that players in the tourism industry are employing to increase their attractiveness to domestic tourists. This will be important in assessing whether these businesses have adopted any changes after international tourists were scared from visiting the country due to terrorism.

\section{References}

[1] Allen, D. E., and Yap, G. (2009). Modelling Australian domestic tourism demand: A panel data approach. School of Accounting, Finance and Economics, Edith Cowan University.

[2] Asche, H. (2008). Contours of China "s "Africa Mode" and who may benefit. Journal of Current Chinese Affairs, 37(3), 165-180.

[3] Ajzen, I. (2002). Perceived Behavioral Control, SelfEfficacy, Locus of Control, and the Theory of Planned Behavior. Journal of Applied Social Psychology, 32, 665-683.

[4] Bell, C. (2007). Using SPSS, Journal of Statistics, 22(1), pp.13-19

[5] Bringas, N. and Israel, J.I. (2004). El turismo alternativo: una opción para el desarrollo local en dos comunidades indígenas de Baja California. Economía, Sociedad y Territorio, Vol. 4, No.15, pp.551-588

[6] Cooper, D. and Schindler. P. (2003). Business Research Methods. (8th Ed.). New Delhi: Tata McGraw Hill.

[7] Dieke, P. U. (2000). Developing tourism in Africa: issues for policy consideration. The Development Policy Management Forum, 7(1), 25-31

[8] Drăghici, C. C., Peptenatu, D., Pintilii, R. D., Peptenatu, A., and Stoian, D (2010). The role of infrastructure in generating multiplying effects for tourism development. Case study the influence area of the city Râmnicu Vâlcea.

[9] Guyer, C., Pollard, J. (1997). Cruise visitor impressions of the environment of the Shannon-Erne waterways system. Journal of Environmental Management, 51, 199-215.

[10]Hall, D. and Richards, G. (2003) Tourism and Sustainable Community Development, Routledge, London.

[11] Horrigan, D. (2009). Branded content: A new model for driving tourism via film and branding strategies. Tourismos, 4(3), 51-65

[12] Hughes, H. (2002). Culture and tourism: A framework for further analysis. Managing Leisure, 7(3), 164-175.

[13] Irandu, E. M. (2004). The role of tourism in the conservation of cultural heritage in Kenya. Asia Pacific Journal of Tourism Research, 9(2), 133-150.

[14] Joppe, P. (2000). Research Methodology. Third Edition. Pearson Publishers. London.UK.

[15] Kayat, K. (2010). The nature of cultural contribution of a community-based homestay programme. Tourismos, 5(2), 145-159.
[16]Kombo, K, D. and Tromp, A. L. D. (2006). Proposal and thesis writing: An introduction Nairobi: Pauline Publications Africa

[17] Korstanje, M. E. (2013). Preemption and Terrorism. When the Future Governs. Cultura, 10(1), 167-184.

[18] Kothari, C. (2004). Pretesting in questionnaire design: The impact of respondent characteristics on error detection. Journal of the Market Research Society, 36(October), 295-314.

[19] Lehtolainen, M. (2003). Public infrastructure investments and their role in tourism development in the Finnish lake region. Proceedings of Lake Tourism Conference.

[20] Lehtolainen, M. (2003). Public infrastructure investments and their role in tourism development in the Finnish lake region. Proceedings of Lake Tourism Conference.

[21] Lindauer, L. (2009). Rational Choice Theory, Grounded Theory, and Their Applicability to Terrorism. Policy Research Practice, The Heinz Journal, 9(2).

[22] López-Guzmán, T., Borges, O., and Cerezo, J. M. (2011). Community-based tourism and local socioeconomic development: A case study in Cape Verde. African Journal of Business Management, 5(5), 16081617.

[23] Maneesha D.(2006). The salience of species difference for feminist theory, Hastings Women's Law Journal, 17(1), pp. 1-38.

[24] Mann, M. (2000) The Community Tourism Guide: Exciting Holidays for Responsible Travelers. London: Earthscan

[25] Mansfeld, Y., and Pizam, A. (Eds.). (2006). Tourism, security and safety. Routledge.

[26]Miller, K., (2005). Communications theories: perspectives, processes, and contexts. New York McGraw Hill.

[27] Mohamed, G.A. (2008). Egypt's image as a tourist destination - a perspective of foreign tourists. Tourismos, 3(1), 36-65

[28] Mthembu, N. (2009). Tourism crime, safety and security in the Umhlathuze district municipality, Kwazulu-Natal. Unpublished doctoral dissertation, Faculty of Arts in Partial Fulfillment of the Requirements for the Master's in Recreation and Tourism at the Department of Recreation and Tourism, University of Zululand

[29] Mugenda, O. M., and Mugenda, A. G. (2003). Research methods: Quantitative and qualitative approaches. Nairobi, Kenya: Act Press.

[30] Mugenda, O.M and Mugenda, A.G. (2003).Research Methods. Nairobi: Acts Press.

[31] Murphy, P. E., and Murphy, A. E. (2004). Strategic management for tourism communities: Bridging the gaps. Clevedon: Channel View Publications.

[32] Olorunfemi, F., and Raheem, U. A. (2008). Sustainable Tourism Development in Africa: the imperative for Tourists/host communities security. Journal of Sustainable Development in Africa, 10(3), 201-220.

[33] Ondicho, T. G. (2000). International tourism in Kenya: Development, problems and challenges. Eastern Africa Social Science Research Review, 16(2), 49-70.

[34] Pantelescu, A. M (2012). Trends in International Tourism. Cactus Tourism Journal, 3(2), 31-35 


\section{International Journal of Science and Research (IJSR) \\ ISSN (Online): 2319-7064}

Index Copernicus Value (2013): 6.14 | Impact Factor (2014): 5.611

[35] Porter, M. E. and Kramer, M. R. (2006). Strategy and Society: The link between competitive advantage and corporate social responsibility, Harvard Business Review, Dec 2006, pp.78-92.

[36] Porter, M. E. (2008). The Five Competitive Forces That Shape Strategy, Harvard Business Review, 79-93.

[37] Ranga, M., and Pradhan, P. (2014). Terrorism terrorizes tourism: Indian tourism effacing myths? IJSSTH, 1(5), 26-39.

[38] Rao, R. S. (2014). Emerging trends in hospitality and tourism. International Journal of Research 1-8

[39]Richards, G., and Wilson, J. (2007). Tourism development trajectories: From culture to creativity. Tourism, creativity and development, 1-33.

[40] Salazar, N. B. (2012). Community-based cultural tourism: Issues, threats and opportunities. Journal of Sustainable Tourism, 20(1), 9-22.

[41] Saunders, M., Lewis, P. and Thornhill, A. (2003). Research methods for business students ( $3^{\text {rd }}$ ed.). England: Pearson Education Limited.

[42] Schultz, J., (2006). Vehicle of the self: The social and cultural work of the H2 Hummer. Journal of Consumer Culture, 6, (3) 57-86.

[43] Schram, Sanford F. and Brian Caterino, eds. (2006). Making Political Science Matter: Debating Knowledge, Research, and Method. New York and London: New York University Press.

[44] Solomon, M., Russell-Bennett, R., and Previte, J. (2012). Consumer behaviour. Pearson Higher Education AU.

[45]UNWTO, (2005). Cultural Tourism and Poverty Alleviation: The Asia-Pacific Perspective.

[46] Why tourism, World Tourism Organization available at http://www2.unwto.org/en/content/whytourism accessed March 10, 2013

[47] Wiener C., (2006), Imionaalaoke moana: Learning the ways of the oceans, an evaluation of ocean education and marine tourism practices in Hawai,i, Unpublished MES paper thesis, York University, Toronto, ON, Canada

[48] Williams, J., and R. Lawson. (2001). Community Issues and Resident Opinions of Tourism. Annals of Tourism Research, 28, 269-290.

[49] Woodside, A. G., and Chebat, J. C. (2001). Updating Heider's balance theory in consumer behavior: A Jewish couple buys a German car and additional buyingconsuming transformation stories. Psychology and Marketing, 18(5), 475-495.

[50]Zinbarg, M. (2005). Research Methods, Second edition. New Jersey. USA Pearson Publishers 